\title{
WeEd SupPREsSion IN THE Formation OF BRACHIARIAS UNDER Three SOWING METHODS ${ }^{1}$
}

\author{
Supressão de Plantas Daninhas na Formação de Braquiárias Sob Três Métodos de Semeadura
}

LIMA, S.F. ${ }^{2}$, TIMOSSI, P.C. ${ }^{2}$, ALMEIDA, D.P. ${ }^{3}$, and SILVA, U.R. ${ }^{4}$

\begin{abstract}
The success of conservation systems such as no-till depends on adequate soil cover throughout the year, which is possible through the use of cover crops. For this purpose the species belonging to the genus Urochloa has stood out by virtue of its hardiness and tolerance to drought. Aiming ground cover for the no-till system, the objective was to evaluate the establishment of two species of the genus Urochloa, in three sowing methods, in the weed suppression and the sensitivity of these forages to glyphosate. The study design was a randomized block with a $2 \times 3 \times 3$ factorial arrangement, in which factor A was composed of Urochloa ruziziensis and Urochloa hybrid CIAT $36087 \mathrm{cv}$. Mulato II, factor B was formed by sowing methods: sown without embedding, sown with light embedding and sown in rows, and factor $\mathrm{C}$ was composed of three doses of glyphosate $\left(0.975,1.625\right.$ and $2.275 \mathrm{~kg} \mathrm{ha}^{-1}$ of acid equivalent). For determination of weed suppression, assessment of biomass yield and soil cover was performed, by brachiaria and weeds, at 30, 60, 90, 120 and 258 days after sowing. Visual assessment of the desiccation efficiency at 7 and 14 days after herbicide application was performed. It is concluded that embedding Urochloa seeds stands out in relation to sowing in the soil surface. Urochloa ruziziensis is more efficient in the dry weight yield, weed suppression, in addition to being more sensitive to glyphosate herbicide.
\end{abstract}

Keywords: no-till, crop-livestock integration, Urochloa sp., desiccation, glyphosate.

RESUMO - O sucesso de sistemas conservacionistas, como o plantio direto, depende da cobertura do solo durante todo o ano, o que é possivel através da utilização de plantas de cobertura. Com esse propósito, as espécies do gênero Urochloa têm se destacado em razão de sua rusticidade e tolerância ao déficit hídrico. Almejando a cobertura do solo para o sistema plantio direto, objetivou-se neste estudo avaliar o estabelecimento de duas espécies do gênero Urochloa, em três métodos de semeadura, na supressão de plantas daninhas, bem como a sensibilidade dessas forrageiras ao glyphosate. O delineamento adotado foi o de blocos casualizados, em arranjo fatorial $2 \times 3 \times 3$, no qual o fator A foi composto por Urochloa ruziziensis e Urochloa híbrida CIAT $36087 \mathrm{cv}$. Mulato II; o fator B foi estabelecido pelos métodos de semeadura a lanço, a lanço com incorporação e em linha; e o fator C foi composto por três doses de glyphosate $10,975,1,625$ e 2,275 $\mathrm{kg} \mathrm{ha}^{-1}$ de equivalente ácido). Para determinação da supressão de plantas daninhas, foram realizadas avaliações de produção de fitomassa e cobertura do solo, pelas braquiárias e plantas daninhas, aos 30, 60, 90, 120 e 258 dias após a semeadura. Foram feitas avaliações visuais de eficiência da dessecação aos 7 e 14 dias após a aplicação do herbicida. Conclui-se que a incorporação de sementes de Urochloa se destaca em relação à semeadura a lanço. Urochloa ruziziensis é mais eficiente na produção de massa vegetal, supressão de plantas daninhas, além de ser mais sensivel ao herbicida glyphosate.

Palavras-chave: plantio direto, integração lavoura-pecuária, Urochloa sp., dessecação, glyphosate.

Recebido para publicação em 16.4.2014 e aprovado em 1.7.2014.

2 Universidade Federal de Goiás, Jataí-GO, Brasil, <suzete.lima@yahoo.com.br>; ${ }^{3}$ Unesp, Jaboticabal-SP, Brasil; ${ }^{4}$ Emater, Itarumã-GO, Brasil.

Planta Daninha, Viçosa-MG, v. 32, n. 4, p. 699-707, 2014 


\section{INTRODUCTION}

The sowing of forage grass after cultivation of the crop, replacing fallow, becomes a viable alternative to soil cover and consecutively weed suppression, leading to decreased soil seed bank over the years (Nunes et al., 2006; Severino et al., 2006; Ikeda et al., 2007; Timossi et al., 2007; Noce et al., 2008). The presence of vegetation cover on the soil in adequate amounts for direct sowing, with the use of forage grasses, favors the implementation of the integrated croplivestock system, since these species provide enough plant mass to be available in animal feed in the period off-season, mitigating the effect of seasonality of the forage grass. In this context, the genus Urochloa have shown increased use in cultivation after the summer harvest.

The establishment and development of plants are relevant for the formation of vegetation cover, which is directly related to the method and depth of sowing. In areas of direct sowing, there have been several studies on the establishment of fodder intercropped with annual crops (Jakelaitis et al., 2004, 2005; Borghi \& Crusciol, 2007); however, with regard to the exclusive establishment of forage, for forming plant cover in areas of direct sowing, there are still few studies. Thus, it becomes important to identify the agricultural practices and sowing methods that promote soil cover in the shortest time and that are efficient in biomass yield, in addition to suppressing weed community.

In the Cerrado region (vast tropical savanna ecoregion of Brazil), the genus Urochloa has distinguished itself in the formation of ground cover for direct sowing because it keeps growing during the dry season (Machado \& Assis, 2010), plus the ability to excel competition with weeds (Gimenes Jr. et al., 2011). Thus, it becomes important to select species of Urochloa in terms of the productive capacity and which are adapted to the adopted management. In this context, Urochloa ruziziensis presents advantages because it is easily controlled by herbicides adopted in desiccation (Brighenti et al., 2011). However, most studies assess the formation of vegetation cover by Urochloa brizantha and Urochloa decumbens. Urochloa hybrid CIAT $36087 \mathrm{cv}$. Mulato II shows increased biomass yield and tolerance to prolonged periods of drought as important features (Argel et al., 2007). However, there is little information on the use of this material in a direct sowing system.

In order to assess the establishment of vegetation cover on soil in direct sowing areas, besides the suppression of the weed community and its susceptibility to glyphosate, different methods of sowing Urochloa ruziziensis and Urochloa hybrid CIAT $36087 \mathrm{cv}$. Mulato II were surveyed.

\section{MATERIALS AND METHODS}

The research was conducted in southwestern Goiás. The experimental area was classified as clayey red oxisol (Embrapa, 2006). Climatological data for the period of conducting the research (Figure 1) were obtained from the weather station INMET (Instituto Nacional de Meteorologia - National Institute of Meteorology), located 1,500 m from the experimental area.

The brachiaria sowing was done from the soybean harvest, on 03/30/2012, after desiccation of the area with glyphosate at $1.44 \mathrm{~kg} \mathrm{ha}^{-1}$ of acid equivalent.

The experimental design was a randomized block design with four replications in a $2 \times 3 \times 3$ factorial arrangement. Factor A comprised Urochloa ruziziensis and Urochloa hybrid CIAT 36087 cv. Mulato II; factor B was established by the broadcast sowing methods, sown with light embedding by 'closed' harrows and in rows; and factor $\mathrm{C}$ was established by three doses of glyphosate $(0.975,1.625$ and $2.275 \mathrm{~kg} \mathrm{ha}^{-1}$ of equivalent acid). Plots without brachiaria were also kept, enabling the development of spontaneous vegetation (fallow). The area of each plot was $4 \mathrm{~m}$ wide by $15 \mathrm{~m}$ long, totaling $60 \mathrm{~m}^{2}$. In desiccation, the plots were divided, and shall have dimensions of $4 \mathrm{~m}$ wide by $6.6 \mathrm{~m}$ long, totaling $26.4 \mathrm{~m}^{2}$.

Sowing rate of brachiarias followed the recommendation of points of cultural value (VC); 400 points of $\mathrm{VC} \mathrm{ha}^{-1}$ were used for broadcast sowing and sown with embedding, resulting in $8 \mathrm{~kg} \mathrm{ha}^{-1}$ of viable seeds for 


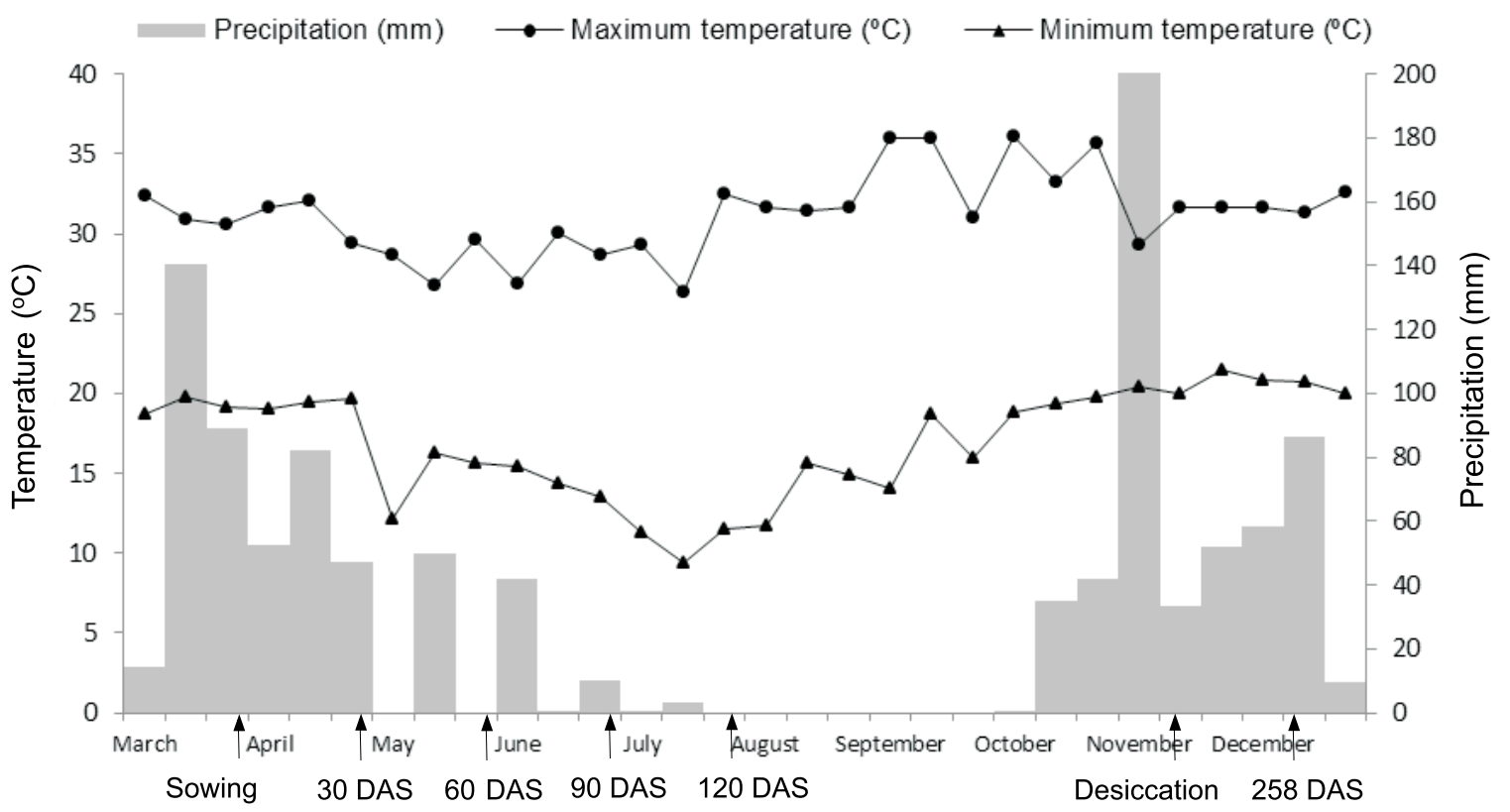

Figure 1 - Mean maximum and minimum air temperature and total precipitation in periods of ten days, during the conduct of the experiment.

Brachiaria ruziziensis and $5 \mathrm{~kg} \mathrm{ha}^{-1}$ of viable seeds for the Brachiaria hybrid, and 240 points of $\mathrm{VC} \mathrm{ha}^{-1}$ for sowing in rows, resulting in $4.8 \mathrm{~kg} \mathrm{ha}^{-1}$ of viable seeds for Brachiaria ruziziensis and $3 \mathrm{~kg} \mathrm{ha}^{-1}$ of viable seeds for Brachiaria hybrid. For Urochloa hybrid CIAT 36087 cv. Mulato II, pelleted seeds were used, and for Urochloa ruziziensis, seeds treated with the fipronil insecticide. In the two types of broadcast sowing, the seeds were sown manually in total area. In the treatment with embedding, operation of light grading with 'closed' harrowing was performed at a depth of $0.05 \mathrm{~m}$. For sowing in rows, eight rows in each plot were established, spaced $0.45 \mathrm{~m}, 0.05 \mathrm{~m}$ depth, simulating the adoption of a by tractor seeder.

At 30 and 60 days after sowing (DAS), the specific composition of plant species present in each plot was determined; plants were identified, cut close to the ground, separated by species, placed in paper bags and taken to drying in a forced hot air chamber at $65{ }^{\circ} \mathrm{C}$ for subsequent determination of dry weight. The yield of plant mass provided by the cover crop was assessed at 30, 60, 90 and 120 DAS. For this, the plants were cut at ground level and separated into brachiaria plants and weeds. In both evaluations, in each experimental plot, three boxes of $0.50 \mathrm{~m}$ of sides $\left(0.25 \mathrm{~m}^{2}\right)$ were sampled, randomly cast.

The percentage of vegetation cover on land, provided by brachiaria and the weed species, was determined at 30, 60 and 90 DAS by the row intercept technique (Brower \& Zar, 1984). In the technique of row intercept a rope with 100 intervals, spaced $0.05 \mathrm{~m}$ was used, adding $5 \mathrm{~m}$ long. This assessment was done in three random points in each experimental plot, in which the ranges that presented vegetation cover by the cover plant and the weeds were counted.

On 11/13/2012 (228 DAS) desiccation of the experimental area with glyphosate herbicide was held. At 30 days after desiccation, there was the collection of plant mass of brachiaria with the use of a box of $0.5 \mathrm{~m}$ of sides $\left(0.25 \mathrm{~m}^{2}\right)$ in three random points in each plot to determine dry weight provided by brachiaria after desiccation. During this period, the assessment of the percentage of vegetation cover on the soil was also done.

In the application of herbicide spray research was used, maintained at a constant pressure by $\mathrm{CO}_{2}$, with bars of six nozzles fitted with tips TT 110015 , spaced $0.5 \mathrm{~m}$, and a spray volume of $200 \mathrm{~L} \mathrm{ha}^{-1}$. The application was done 
in the morning, in the conditions of air temperature of $29.7^{\circ} \mathrm{C}$, air relative humidity of $86 \%$, cloud cover of $60 \%$ and soil moisture at the surface. Both brachiaria species were at a vegetative stage. At 7 and 14 days after application (DAA), visual efficiency ratings of desiccation were performed (Gazziero et al., 1995), in which was adopted the scale of grades of 0 to $100 \%$, being 0 corresponding to the absence of injuries in the plants and 100 to the death of the plants.

Data for plant stand, dry weight yield, percent of cover on the soil and percentage of control were subjected to analysis of variance and subsequently, when needed, the comparison of means by Tukey test at 5\% significance (Banzato \& Kronka, 2006).

\section{RESULTS AND DISCUSSION}

The weeds in the experimental area were identified: Digitaria horizontalis (common names include crabgrass, finger-grass, and fonio), Eleusine indica (Indian goosegrass, wiregrass, crowfootgrass), Pennisetum setosum (fountaingrasses), Chamaesyce hirta (pill bearing spurge), Bidens pilosa (its many common names include beggar-ticks, cobbler's pegs, and Spanish needle) and Commelina benghalensis (commonly known as Benghal dayflower, tropical spiderwort, or wandering Jew).

Depending on the specific composition of the weed community, the weed species were grouped into monocotyledons and eudicotyledons at 30 and 60 DAS (Figure 2). The reduction in the number of weeds from 30 to 60 DAS was noticeable, characterizing the beginning of the occupation of space by the brachiarias. This reduction was also observed in the weed community, since the dominant weeds develop, occupying the area, which prevents the growth of the less competitive ones. In the presence of brachiaria, there was lower plant density of competing species. It was also found that, in most situations, the absolute value of the number of eudicotyledons plants exceeds that of monocotyledons.

In Brachiaria hybrid there was a higher absolute number of emerged weeds (Figure 2),

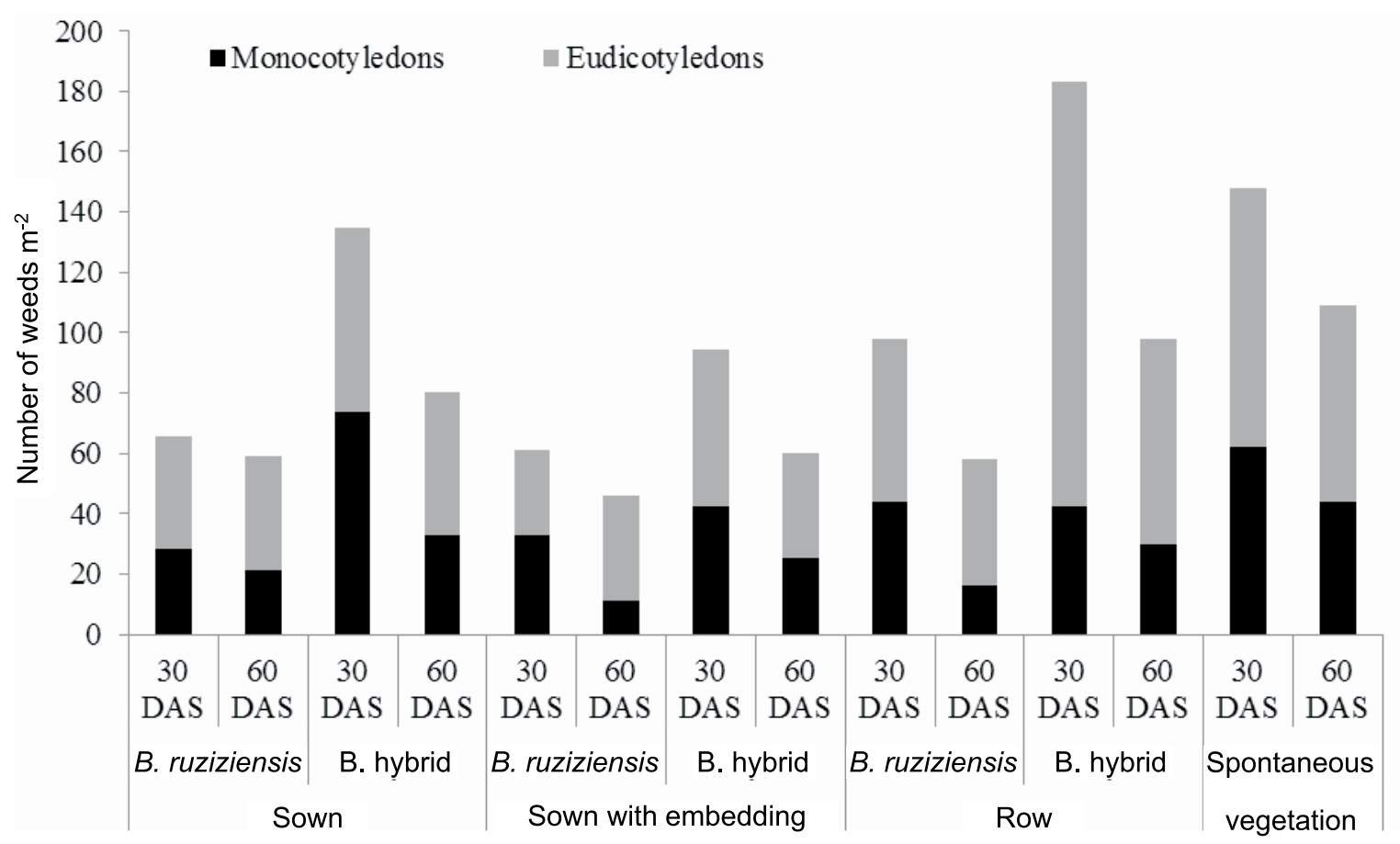

Figure 2 - Number of monocotyledons and eudicotyledons weeds per $\mathrm{m}^{2}$ present in Urochloa ruziziensis (Brachiaria ruziziensis) and Urochloa hybrid (Mulato grass II), in the methods of broadcast sowing, sown with embedding and in rows, and in fallow, at 30 and 60 days after sowing (DAS). 
indicating less potential for competition with the weed community in its early development. Based on the results, it can be stated that this species has a slow initial growth when compared to the Urochloa ruziziensis. Thus, it is prudent to adopt the brachiaria species with a higher potential for weed suppression, which will reflect in establishing in the area in a shorter period.

Table 1 shows the stand of brachiaria plants at 30 and 60 DAS, in which a significant interaction was observed at the first assessment. At 60 DAS, a higher number of emerged plants was seen in the Urochloa ruziziensis. However, the sowing method did not promote significant differences in the plant stand of this species.

The unfolding of significant interaction, obtained at 30 DAS for the stand of brachiaria plants is presented in Table 2. It is noticed that only in the broadcast sowing there was no difference of plant stand by the two species of brachiaria. In Urochloa ruziziensis, the methods of sowing by embedding seeds provided a greater number of plants. According to Garcia et al. (1998), embedding seeds improves their distribution in the soil profile and provides greater protection, which favors germination. In contrast, the seeds deposited on the soil surface are susceptible to predators such as birds and rodents, and the action of soil microorganisms (Pitelli \& Durigan, 2001).
In Brachiaria hybrid, the sowing method did not promote a significant difference in plant stand, showing that the seeds of this species have greater stability in germination on the soil surface. This probably is due to the fact that the seeds are pelletized, which favored the establishment in adverse conditions (Baudet et al., 2004; Argel et al., 2007).

For pasture establishment are recommended 15-20 brachiaria plants by $\mathrm{m}^{2}$ (Valle et al., 2001). Only Brachiaria ruziziensis provided a number of plants adequate for forming forage plants. Thus, for the Brachiaria hybrid an option for obtaining a greater number of plants would be the use of a higher sowing rate.

The hybrid brachiaria provided less yield of plant mass, at 60, 90, 120 and 258 DAS (Table 3), corroborating the results of Pariz et al. (2010), who observed a higher dry matter yield of Brachiaria ruziziensis in relation to Brachiaria hybrid (Capim mulato II). In this research, the lowest dry matter yield of Brachiaria hybrid may be related to the lower density of plants obtained in this species.

In both brachiaria species, the sowing methods with seeds embedding proved superior. However, by the time of handling, only Brachiaria ruziziensis obtained higher plant mass than what is recommended for direct sowing (Alvarenga et al., 2001). Thus, this

Table 1 - Values of F, least significant difference (LSD) and coefficients of variation (CV\%), applied to the means of percentage of control of brachiaria, at 30 and 60 days after sowing (DAS)

\begin{tabular}{|c|c|c|c|}
\hline & \multirow{2}{*}{ Variables } & \multicolumn{2}{|c|}{ Brachiaria plant stand (plants $\mathrm{m}^{-2}$ ) } \\
\hline & & $30 \mathrm{DAS}$ & 60 DAS \\
\hline \multirow{3}{*}{$\mathrm{F}$} & Species $(\mathrm{E})$ & $46.44 * *$ & $42.70 * *$ \\
\hline & Sowing (S) & $12.46^{* *}$ & $2.40^{\mathrm{ns}}$ \\
\hline & $\mathrm{E} \times \mathrm{S}$ & $13.55 * *$ & $0.19^{\text {ns }}$ \\
\hline \multirow{2}{*}{ Species (E) } & Brachiaria ruziziensis & & $17 \mathrm{a}$ \\
\hline & Brachiaria hybrid & & $7 \mathrm{~b}$ \\
\hline LSD & & & 3 \\
\hline \multirow{3}{*}{ Sowing (S) } & Sown & & 10 \\
\hline & Sown with embedding & & 14 \\
\hline & Row & & 13 \\
\hline LSD & & & 5 \\
\hline $\mathrm{CV}(\%)$ & & 29.91 & 31.39 \\
\hline
\end{tabular}

Means followed by the same letter in the column do not differ among themselves by the Tukey test at $\mathrm{p}<0.05$. 
Table 2 - Stand of brachiaria plants (plants $\mathrm{m}^{-2}$ ), at 30 days after sowing (DAS), depending on the sowing methods studied

\begin{tabular}{|l|c|c|}
\hline \multirow{2}{*}{\multicolumn{1}{|c|}{ Sowing }} & \multicolumn{2}{|c|}{ Brachiaria species } \\
\cline { 2 - 3 } & $\begin{array}{c}\text { Brachiaria } \\
\text { ruziziensis }\end{array}$ & $\begin{array}{c}\text { Brachiaria } \\
\text { hybrid }\end{array}$ \\
\hline Sown & $8 \mathrm{bA}$ & $8 \mathrm{aA}$ \\
\hline Sown with embedding & $27 \mathrm{aA}$ & $8 \mathrm{aB}$ \\
\hline Row & $21 \mathrm{aA}$ & $8 \mathrm{aB}$ \\
\hline LSD & & \\
\hline Sowing within species & \multicolumn{2}{|c|}{7.36} \\
\hline Species within sowing & \multicolumn{2}{|c|}{6.04} \\
\hline
\end{tabular}

Averages in the same row, followed by the same capital letters, and in the same column followed by the same lowercase letters do not differ by Tukey test at $\mathrm{p}<0.05$. species could be partially provided for animal consumption in the period of scarcity of forage, becoming a source of income for the producer.

The unfolding of significant interaction for dry matter yield obtained at 30 DAS is presented in Table 4. At 30 DAS, Brachiaria ruziziensis provided the highest yield of dry mass, indicating greater occupation of the area in a shorter period, which will be reflected in the greater vegetation cover on the soil and weed suppression. According to Gimenes Jr. et al. (2011), the largest occupation of the area by the forage species promotes greater competition for environmental resources, being more efficient in suppressing weeds.

Table 3 - Values of F, least significant difference (LSD) and coefficients of variation (CV\%), applied to the yield means of dry weight of the brachiaria, at 30,60, 90, 120 and 258 days after sowing (DAS)

\begin{tabular}{|c|c|c|c|c|c|c|}
\hline & \multirow{2}{*}{ Variables } & \multicolumn{5}{|c|}{ Dry weight of brachiaria $\left(\mathrm{kg} \mathrm{ha}^{-1}\right)$} \\
\hline & & 30 DAS & $60 \mathrm{DAS}$ & 90 DAS & $120 \mathrm{DAS}$ & $258 \mathrm{DAS}$ \\
\hline \multirow{3}{*}{$\mathrm{F}$} & Species (E) & $156.27 * *$ & $110.76^{* *}$ & $152.59 * *$ & $187.64 * *$ & $66.47 * *$ \\
\hline & Sowing (S) & $36.95 * *$ & $2.58^{\mathrm{ns}}$ & $7.05 * *$ & $2.86^{\mathrm{ns}}$ & $7.56^{* *}$ \\
\hline & $\mathrm{E} \times \mathrm{S}$ & $18.86^{* *}$ & $0.26^{\mathrm{ns}}$ & $2.59^{\mathrm{ns}}$ & $1.03^{\mathrm{ns}}$ & $2.74^{\mathrm{ns}}$ \\
\hline \multirow{2}{*}{ Species (E) } & Brachiaria ruziziensis & & $2057 \mathrm{a}$ & $6050 \mathrm{a}$ & $6840 \mathrm{a}$ & $9687 \mathrm{a}$ \\
\hline & Brachiaria hybrid & & $523 \mathrm{~b}$ & $1917 \mathrm{~b}$ & $3052 \mathrm{~b}$ & $6461 \mathrm{~b}$ \\
\hline LSD & & & 310 & 712 & 589 & 842 \\
\hline \multirow{3}{*}{ Sowing (S) } & Sown & & 1061 & $3142 \mathrm{~b}$ & 4646 & $7004.49 \mathrm{~b}$ \\
\hline & Sown with embedding & & 1446 & $4652 \mathrm{a}$ & 4785 & $8438.07 \mathrm{a}$ \\
\hline & Row & & 1362 & $4155 \mathrm{ab}$ & 5407 & $8779.17 \mathrm{a}$ \\
\hline LSD & & & 463 & 1064 & 879 & 1257 \\
\hline CV $(\%)$ & & 21.20 & 27.67 & 20.58 & 13.69 & 11.99 \\
\hline
\end{tabular}

Means followed by the same letter in the column do not differ among themselves by the Tukey test at $\mathrm{p}<0.05$.

Table 4 - Yield of dry weight of brachiarias $\left(\mathrm{kg} \mathrm{ha}^{-1}\right)$ at 30 days after sowing (DAS), depending on the sowing methods studied

\begin{tabular}{|l|c|c|}
\hline \multirow{2}{*}{ Sowing } & \multicolumn{2}{|c|}{ Brachiaria species $\left(\mathrm{kg} \mathrm{ha}^{-1}\right)$} \\
\cline { 2 - 3 } & $\begin{array}{c}\text { Brachiaria } \\
\text { ruziziensis }\end{array}$ & $\begin{array}{c}\text { Brachiaria } \\
\text { hybrid }\end{array}$ \\
\hline Sown & $87.16 \mathrm{cA}$ & $39.97 \mathrm{aB}$ \\
\hline Sown with embedding & $274.27 \mathrm{aA}$ & $71.56 \mathrm{aB}$ \\
\hline Row & $194.30 \mathrm{bA}$ & $53.97 \mathrm{aB}$ \\
\hline LSD & \multicolumn{2}{|c|}{46.77} \\
\hline Sowing within species & \multicolumn{2}{|c|}{38.36} \\
\hline Species within sowing & \multicolumn{2}{|c|}{} \\
\hline
\end{tabular}

Averages in the same row, followed by the same capital letters, and in the same column followed by the same lowercase letters do not differ by Tukey test at $\mathrm{p}<0.05$.
Soil cover by the total of species present in the area and cover by brachiarias were higher in the Urochloa ruziziensis during the three periods assessed (Table 5). Regarding the sowing method, the highest percentage of the total soil cover was obtained in broadcast sowing, which did not differ from sowing in rows. At 258 DAS, 30 days after desiccation of the brachiarias, in the three sowing methods, it was found that there was $100 \%$ ground cover in both species.

Urochloa ruziziensis showed a higher percentage of soil cover at 30, 60 and 90 DAS (Table 5). The lowest percentage of coverage from Brachiaria hybrid indicates that 
Weed supression in the formation of brachiarias under three ..

Table 5 - Values of F, least significant difference (LSD) and coefficients of variation (CV \%), applied to the means of percentage of total coverage (CT) of the soil and cover by the brachiaria (CB), at 30, 60 and 90 days after sowing (DAS)

\begin{tabular}{|c|c|c|c|c|c|c|c|}
\hline & \multirow{2}{*}{ Variables } & \multicolumn{2}{|c|}{30 DAS } & \multicolumn{2}{|c|}{$60 \mathrm{DAS}$} & \multicolumn{2}{|c|}{90 DAS } \\
\hline & & CT & CB & $\mathrm{CT}$ & $\mathrm{CB}$ & CT & $\mathrm{CB}$ \\
\hline \multirow{3}{*}{$\mathrm{F}$} & Species (E) & $7.23 *$ & $67.85 * *$ & $16.62 * *$ & $199.38 * *$ & $20.28 * *$ & $154.87 * *$ \\
\hline & Sowing (S) & $5.15^{*}$ & $4.20 *$ & $2.29^{\mathrm{ns}}$ & $10.29 * *$ & $4.60 *$ & $6.27 *$ \\
\hline & $\mathrm{E} \times \mathrm{S}$ & $1.15^{\mathrm{ns}}$ & $1.28^{\mathrm{ns}}$ & $2.17^{\mathrm{ns}}$ & $1.70^{\mathrm{ns}}$ & $2.90^{\mathrm{ns}}$ & $1.24^{\mathrm{ns}}$ \\
\hline \multirow{2}{*}{ Species (E) } & Brachiaria ruziziensis & $38 \mathrm{a}$ & $21 \mathrm{a}$ & $85 \mathrm{a}$ & $61 \mathrm{a}$ & $100 \mathrm{a}$ & $80 \mathrm{a}$ \\
\hline & Brachiaria hybrid & $30 \mathrm{~b}$ & $8 \mathrm{~b}$ & $71 \mathrm{~b}$ & $22 \mathrm{~b}$ & $96 \mathrm{~b}$ & $32 \mathrm{~b}$ \\
\hline LSD & & 5.63 & 3.36 & 7.19 & 6.00 & 1.73 & 8.24 \\
\hline \multirow{3}{*}{ Sowing (S) } & Sown & $34 \mathrm{ab}$ & $11 \mathrm{~b}$ & 77 & $33 \mathrm{~b}$ & $99 \mathrm{a}$ & $47 \mathrm{~b}$ \\
\hline & Sown with embedding & $29 \mathrm{~b}$ & $17 \mathrm{a}$ & 74 & $46 \mathrm{a}$ & $96 \mathrm{~b}$ & $63 \mathrm{a}$ \\
\hline & Row & $39 \mathrm{a}$ & $15 a b$ & 83 & $46 \mathrm{a}$ & $98 \mathrm{ab}$ & $57 \mathrm{ab}$ \\
\hline LSD & & 8.40 & 5.01 & 10.74 & 8.95 & 2.59 & 12.30 \\
\hline $\mathrm{CV}(\%)$ & & 19.01 & 26.59 & 10.63 & 16.58 & 2.04 & 17.00 \\
\hline
\end{tabular}

Means followed by the same letter in the column do not differ among themselves by the Tukey test at $\mathrm{p}<0.05$.

the weeds have lived with this species by participating more effectively in land cover. As for the sowing method, broadcast sowing with embedding has shown a higher percentage of coverage, not differing from the sowing in rows. According to Jakelaitis et al. (2005), the highest percentage of soil covered by brachiaria favors light interception by the canopy of the forage, limiting this characteristic for weed development. The lowest percentage of coverage by brachiaria in broadcast sowing indicates that in this sowing method there was a highest participation of weeds on the ground cover.

In desiccation, for the percentage of control of brachiaria, there was a significant interaction between the factors, at 7 and

Table 6 - Values of F, least significant difference (LSD) and coefficients of variation (CV\%), applied to the means of percentage of control of brachiaria, at 7 and 14 days after application (DAA)

\begin{tabular}{|c|l|c|c|}
\hline \multirow{2}{*}{ Variables } & \multicolumn{2}{c|}{ Control of brachiaria (\%) } \\
\cline { 3 - 4 } & & 7 DAA & 14 DAA \\
\hline \multirow{4}{*}{ F } & Species (E) & $206.14^{* *}$ & $227.14^{* *}$ \\
\cline { 2 - 4 } & Sowing (S) & $3.15^{*}$ & $10.30^{* *}$ \\
\cline { 2 - 4 } & Dose of herbicide (D) & $5.52^{* *}$ & $60.80^{* *}$ \\
\cline { 2 - 4 } & E x S & $4.69^{*}$ & $7.36^{* *}$ \\
\cline { 2 - 4 } & E X D & $0.26^{\text {ns }}$ & $43.16^{* *}$ \\
\cline { 2 - 4 } & S x D & $2.64^{*}$ & $4.34^{* *}$ \\
\cline { 2 - 4 } & E x S x D & $1.49^{\text {ns }}$ & $2.56^{*}$ \\
\hline \multirow{2}{*}{ CV (\%) } & & 11.68 & 1.28 \\
\hline
\end{tabular}

14 days after application (Table 6). It is noted that, with increasing time, the sensitivity of brachiaria plants to glyphosate increased. At 7 and 14 days after application, Urochloa ruziziensis was more sensitive to the herbicide, presenting greater injury and dying at 14 DAA (Table 7).

Table 7 - Unfolding of significant interaction for the percentage of control of brachiaria, in the three methods of the sowing and in the two species of brachiaria, at 7 and 14 days after application (DAA)

\begin{tabular}{|c|c|c|}
\hline \multirow[b]{2}{*}{ Sowing } & \multicolumn{2}{|c|}{ Brachiaria species } \\
\hline & $\begin{array}{l}\text { Brachiaria } \\
\text { ruziziensis }\end{array}$ & $\begin{array}{c}\text { Brachiaria } \\
\text { hybrid }\end{array}$ \\
\hline \multicolumn{3}{|c|}{$7 \mathrm{DAA}$} \\
\hline Sown & $77.08 \mathrm{aA}$ & $54.58 \mathrm{aB}$ \\
\hline Sown with embedding & $76.67 \mathrm{aA}$ & $44.33 \mathrm{bB}$ \\
\hline Row & $72.92 \mathrm{aA}$ & $52.92 \mathrm{aB}$ \\
\hline \multicolumn{3}{|l|}{ LSD } \\
\hline Sowing within species & \multicolumn{2}{|c|}{7.26} \\
\hline Species within sowing & \multicolumn{2}{|c|}{6.04} \\
\hline \multicolumn{3}{|c|}{14 DAA } \\
\hline Sown & $99.92 \mathrm{aA}$ & $96.75 \mathrm{aB}$ \\
\hline Sown with embedding & $99.83 \mathrm{aA}$ & $95.58 \mathrm{aB}$ \\
\hline Row & $99.67 \mathrm{aA}$ & $93.75 \mathrm{bB}$ \\
\hline \multicolumn{3}{|l|}{ LSD } \\
\hline Sowing within species & \multicolumn{2}{|c|}{1.23} \\
\hline Species within sowing & \multicolumn{2}{|c|}{1.03} \\
\hline
\end{tabular}

Averages in the same row, followed by the same capital letters, and in the same column followed by the same lowercase letters do not differ by Tukey test at $\mathrm{p}<0.05$.

Planta Daninha, Viçosa-MG, v. 32, n. 4, p. 699-707, 2014 
In Urochloa ruziziensis, there was no difference in the percentage of control because of the three sowing methods (Table 7). As for the Brachiaria hybrid, at 14 DAA, the control percentage was lower in the sowing in rows, which is related to higher dry mass and uniformity of soil cover obtained in this sowing method.

At 14 DAA, in the lower dose $\left(0.975 \mathrm{~kg} \mathrm{ha}^{-1}\right)$ of the glyphosate herbicide, the percentage of control of brachiaria was lower in the sowing method in rows (Table 8 ). The higher dry matter yield obtained in this sowing method and the lower susceptibility of Brachiaria hybrid may have contributed to the lower efficiency in the control. In broadcast sowing methods, control percentage was lower only at the lowest dose of the herbicide. As for sowing in rows, increasing the dose of the herbicide provided a better control of brachiaria (Table 8).

At 14 DAA, greater efficiency of desiccation in the three doses of the herbicide was detected in Urochloa ruziziensis (Table 9); damage to this species was higher than that occurring in the Brachiaria hybrid. For this brachiaria the lowest herbicide dose was enough to control it.

Table 8 - Unfolding of significant interaction for the percentage of control of brachiaria, in the three doses of the glyphosate herbicide and in the three sowing methods, at 7 and 14 days after application (DAA)

\begin{tabular}{|c|c|c|c|}
\hline \multirow{2}{*}{ Dose of herbicide } & \multicolumn{3}{|c|}{ Sowing } \\
\hline & Sown & Sown with embedding & Row \\
\hline \multicolumn{4}{|c|}{$7 \mathrm{DAA}$} \\
\hline $0.975 \mathrm{~kg} \mathrm{ha}^{-1}$ & $65.00 \mathrm{aA}$ & $58.75 \mathrm{aAB}$ & $53.75 \mathrm{bB}$ \\
\hline $1.625 \mathrm{~kg} \mathrm{ha}^{-1}$ & $65.00 \mathrm{aAB}$ & $59.00 \mathrm{aB}$ & $68.13 \mathrm{aA}$ \\
\hline $2.275 \mathrm{~kg} \mathrm{ha}^{-1}$ & $67.50 \mathrm{aA}$ & $63.75 \mathrm{aA}$ & $66.88 \mathrm{aA}$ \\
\hline \multicolumn{4}{|l|}{ LSD } \\
\hline Dose of herbicide within sowing & \multicolumn{2}{|c|}{8.90} & \\
\hline Sowing within the dose of herbicide & \multicolumn{2}{|c|}{8.89} & \\
\hline \multicolumn{4}{|c|}{$14 \mathrm{DAA}$} \\
\hline $0.975 \mathrm{~kg} \mathrm{ha}^{-1}$ & $97.00 \mathrm{bA}$ & $95.88 \mathrm{bA}$ & $93.38 \mathrm{cB}$ \\
\hline $1.625 \mathrm{~kg} \mathrm{ha}^{-1}$ & $98.50 \mathrm{abA}$ & $98.00 \mathrm{aA}$ & $97.50 \mathrm{bA}$ \\
\hline $2.275 \mathrm{~kg} \mathrm{ha}^{-1}$ & $99.50 \mathrm{aA}$ & $99.25 \mathrm{aA}$ & $99.25 \mathrm{aA}$ \\
\hline \multicolumn{4}{|l|}{ LSD } \\
\hline Dose of herbicide within sowing & \multicolumn{2}{|c|}{1.51} & \\
\hline Sowing within the dose of herbicide & \multicolumn{2}{|c|}{1.51} & \\
\hline
\end{tabular}

Averages in the same row, followed by the same capital letters, and in the same column followed by the same lowercase letters do not differ by Tukey test at $\mathrm{p}<0.05$.

Table 9 - Unfolding of significant interaction for the percentage of control of brachiaria, in the three doses of the glyphosate herbicide and in the two species of brachiaria, 14 days after application (DAA)

\begin{tabular}{|l|c|c|}
\hline \multirow{2}{*}{ Dose of herbicide } & \multicolumn{2}{|c|}{ Brachiaria species } \\
\cline { 2 - 3 } & Brachiaria ruziziensis & Brachiaria hybrid \\
\hline $0.975 \mathrm{~kg} \mathrm{ha}^{-1}$ & $99.42 \mathrm{aA}$ & $91.42 \mathrm{cB}$ \\
\hline $1.625 \mathrm{~kg} \mathrm{ha}^{-1}$ & $100.00 \mathrm{aA}$ & $96.00 \mathrm{bB}$ \\
\hline $2.275 \mathrm{~kg} \mathrm{ha}^{-1}$ & $100.00 \mathrm{aA}$ & $98.67 \mathrm{aB}$ \\
\hline LSD & & \multicolumn{2}{|c|}{1.23} \\
\hline Dose of herbicide within species & \multicolumn{2}{|c|}{1.03} \\
\hline Species within the dose of herbicide & \multicolumn{2}{|c|}{} \\
\hline
\end{tabular}

Averages in the same row, followed by the same capital letters, and in the same column followed by the same lowercase letters do not differ by Tukey test at $\mathrm{p}<0.05$. 
In Brachiaria hybrid, the highest dose of glyphosate was more effective for its control (Table 9). The greater susceptibility of Urochloa ruziziensis was also verified by Brighenti et al. (2011). According to these authors, knowledge of differential susceptibility among species of the genus Urochloa to glyphosate herbicide enables its economy.

In the researched context, it could be seen that the sowing methods of Urochloa embedding seeds stand out in relation to the method of broadcast sowing without embedding. Urochloa ruziziensis was more efficient in the plant mass yield and weed suppression, and a lower dose of glyphosate was necessary for its desiccation.

\section{LITERATURE CITED}

ALVARENGA, R. C. et al. Plantas de cobertura de solo para sistema plantio direto. Inf. Agropec., v. 22, n. 1, p. 25-36, 2001.

ARGEL, P. J. et al. Cultivar Mulato II (Brachiaria híbrida CIAT 36087): Gramínea de alta qualidade e produção forrageira, resistente às cigarrinhas e adaptada a solos tropicais ácidos. Cali: Centro Internacional de Agricultura Tropical (CIAT), 2007. 22 p.

BANZATTO, D. A.; KRONKA, S. N. Experimentação agrícola. 4.ed. Jaboticabal: Funep, 2006. 237 p.

BAUDET, L.; PERES, W. Recobrimento de sementes. R. Seed News, v. 7, n. 1, p. 20-23, 2004.

BORGHI, E.; CRUSCIOL, C. A. C. Produtividade de milho, espaçamento e modalidade de consorciação com Brachiaria brizantha em sistema plantio direto. Pesq. Agropec. Bras., v. 42, n. 2, p. 163-171, 2007.

BRIGHENTI, A. M. et al. Suscetibilidade diferencial de espécies de braquiária ao herbicida glifosato. Pesq. Agropec. Bras., v. 46, n. 10, p. 1241-1246, 2011.

BROWER, J. E.; ZAR, J. H. Field and laboratory methods for general ecology. 2.ed. Dubuque: Wm. C. Brown Company Publishers, 1984. 226 p.

EMPRESA BRASILEIRA DE PESQUISA AGROPECUÁRIA - EMBRAPA. Centro Nacional de Pesquisa de Solos. Sistema brasileiro de classificação de solos. 2.ed. Rio de Janeiro, 2006. 306 p.

GARCIA, R. et al. Efeito da profundidade de semeadura e da pressão de compactação no solo sobre a emergência de Brachiaria brizantha stapf cv. Marandu. R. Bras. Zootec., v. 27, n. 3, p. 427-433, 1998.
GAZZIERO, D. L. P.; VELINI, E. D.; OSIPE, R. Procedimentos para instalação, avaliação e análise de experimentos com herbicidas. Londrina: Sociedade Brasileira da Ciência das Plantas Daninhas, 1995. 42 p.

GIMENES JR., M. et al. Interferência de Brachiaria ruziziensis sobre plantas daninhas em sistema de consórcio com milho. Semina: Ci. Agr., v. 32, n. 3, p. 931-938, 2011.

IKEDA, F. S. et al. Banco de sementes no solo em sistemas de cultivo lavoura-pastagem. Pesq. Agropec. Bras., v. 42, n. 11, p. $1545-1551,2007$.

JAKELAITIS, A. et al. Manejo de plantas daninhas no consórcio de milho com capim-braquiária (Brachiaria decumbens). Planta Daninha, v. 22, n. 4, p. 553-560, 2004.

JAKELAITIS, A. et al. Influência de herbicidas e de sistemas de semeadura de Brachiaria brizantha consorciada com milho. Planta Daninha, v. 23, n. 1, p. 59-67, 2005.

MACHADO, L. A. Z.; ASSIS, P. G. G. Produção de palha e forragem por espécies anuais e perenes em sucessão à soja. Pesq. Agropec. Bras., v. 45, n. 4, p. 415-422, 2010.

NOCE, M. A. et al. Influência da palhada de gramíneas forrageiras sobre o desenvolvimento da planta de milho e das plantas daninhas. R. Bras. Milho Sorgo, v. 7, n. 3, p. $265-278,2008$

NUNES, U. R. et al. Produção de palhada de plantas de cobertura e rendimento do feijão em plantio direto. Pesq. Agropec. Bras., v. 41, n. 6, p. 943-948, 2006.

PARIZ, C. M. et al. Massa seca e composição bromatológica de quatro espécies de braquiárias semeadas na linha ou a lanço, em consórcio com milho no sistema plantio direto na palha. Acta Sci. An. Sci., v. 32, n. 2, p. 147-154, 2010.

PITELLI, R. A.; DURIGAN, J. C. Ecologia das plantas daninhas no sistema plantio direto. In: ROSSELLO, R. D. Siembra directa em el cono sur. Montevideo: PROCISUR, 2001. p. 203-210.

SEVERINO, F. J.; CARVALHO, S. J. P.; CHRISTOFFOLETI, P. J. Interferências mútuas entre a cultura do milho, espécies forrageiras e plantas daninhas em um sistema de consórcio. III - Implicações sobre as plantas daninhas. Planta Daninha, v. 24, n. 1, p. 53-60, 2006.

TIMOSSI, P. C.; DURIGAN, J. C.; LEITE, G. J. Formação de palhada por braquiárias para adoção do sistema plantio direto. Bragantia, v. 66, n. 4, p. 617-622, 2007.

VALLE, C. B.; EUCLIDES, V. P. B.; MACEDO, M. C. M. Características das plantas forrageiras do gênero Brachiaria. In: SIMPÓSIO SOBRE MANEJO DAS PASTAGENS, 2001, Piracicaba. Anais... Piracicaba: FEALQ, 2001. p. 133-176.

Planta Daninha, Viçosa-MG, v. 32, n. 4, p. 699-707, 2014 